\title{
Zjawisko przemocy rówieśniczej i domowej w opinii dzieci i młodzieży miasta Włocławka
}

\author{
The phenomenon of peer and domestic violence in the \\ opinion of children and young people in Wloclawek
}

\author{
PAULINA SMYK ${ }^{1}$, MARTA LEWICKA² \\ ${ }^{1}$ Zakład Pielęgniarstwa Pediatrycznego, Collegium Medicum im. Ludwika Rydygiera \\ w Bydgoszczy, UMK w Toruniu \\ ²Oddział Anestezjologii i Intensywnej Terapii Dziecięcej, Wojewódzki Szpital Dziecięcy \\ im. J. Brudzińskiego w Bydgoszczy
}

DOI: http://dx.doi.org/10.21784/IwP.2018.001

ISSN: 2541-1846

\section{Streszczenie:}

Wstęp. Zjawisko przemocy w środowisku szkolnym jest powszechnym zjawiskiem. Przemoc szkolna i domowa może przybierać różne formy. Takie zachowanie ma na celu sprawienie bólu, przykrości, przerażenia. W takich sytuacjach ofiara nie może się bronić, a sprawca ma poczucie bezkarności.

Cel. Celem badania jest ocena powszechności zjawiska przemocy w środowisku szkolnym i domowym oraz wstępna identyfikacja problemu.

Materiał i metody. Badanie zjawiska przemocy rówieśniczej i domowej zostało przeprowadzone w grupie 369 uczniów szkoły podstawowej, klas gimnazjalnych szkoły podstawowej oraz szkoły średniej na terenie miasta Włocławek przy użyciu kwestionariusza ankiety własnego autorstwa. Badanie stanowiło część większych badań dot. zachowań dzieci i młodzieży.

Wyniki. Większość uczniów 67,2\% nie doświadcza przemocy w środowisku szkolnym, problem przemocy dotyczy 32,1\% dzieci, najczęściej występuje wśród uczniów szkoły podstawowej. Najczęstszą formą przemocy są: przekleństwa, wyśmiewanie, kłótnie. Zdecydowana większość przebadanych dzieci i młodzieży nie doświadcza przemocy w środowisku domowym. Wśród 
uczniów, których dotyczył problem przemocy domowej większość nie poinformowała nikogo o stosowanej przemocy.

Wnioski. Badania wskazują niewielki wzrost agresji werbalnej i relacyjnej. W porównaniu do wcześniejszych badań obserwuje się wzrost liczby uczniów deklarujących problem przemocy w szkole. Zjawisko przemocy rówieśniczej powinno być kontrolowane i przerywane przez nauczycieli, z uwagi na późniejsze problemy zdrowotne i emocjonalne, które może spowodować u ofiary.

Słowa kluczowe: przemoc, dzieci, młodzież

\begin{abstract}
:
Introduction. The problem of violence in the school environment is very common. School violence and domestic violence have different forms. Such behavior aims to cause pain, distress, and terror. In such situations, the victims cannot defend themselves, and the perpetrator has a sense of impunity.

Aim. The aim of the study is tro asses the frequency of peer and domestic violence and the initial identification of the problem.

Materials and methods. The study of peer and domestic violence problem included a group of 369 children of primary school, junior high school and high school in the city of Wloclawek. A questionnaire was used. The study was part of a larger study on the behavior of children and adolescents.

Results. Most students (67.2\% )do not experience violence in the school environment, the problem of violence affects $32.1 \%$ of children, most often primary school students. The most common forms of violence are: curses, ridicule, quarrels. The majority of the examined children and youth do not experience violence in the home environment. Most students affected by domestic violence did not inform anyone about the violence exerted.

Conclusions. Research indicates a slight increase in verbal and relational aggression. Compared to the previous surveys, there is an increase in the number of students reporting the problem of violence at school. The problem of peer violence should be controlled and teachers should react to it strongly because of the potential threat of health and emotional problems that the victim may suffer from in the future.
\end{abstract}

Keywords: violence, children, young people 


\section{Wstęp}

Pojawianie się niepożądanych zachowań takich jak przemoc, jest zjawiskiem powszechnym. Zjawisko przemocy $\mathrm{w}$ środowisku szkolnym sygnalizują zarówno nauczyciele jak i uczniowie, wykazuje ono wyraźnie tendencję rosnącą [1].

Formą zachowania agresywnego jest przemoc występująca wśród uczniów w środowisku szkolnym. Bardzo często przemoc zastępowana jest synonimem zachowania agresywnego, jednak agresja i przemoc wykazują znaczne różnice. Charakterystyczną cechą przemocy jest nierównowaga sił (osoba o przewadze fizycznej lub psychicznej używa przemocy fizycznej lub werbalnej przeciw osobie słabszej). Od pojawienia się chęci skrzywdzenia lub zadania drugiej osobie cierpienia rozpoczyna się przemoc. Występuje kilka form przemocy: przemoc fizyczna, słowna, niewerbalna. Każda z nich może mieć formę bezpośrednią i pośrednią. Do bezpośredniej przemocy fizycznej występującej wśród uczniów w środowisku szkolnym zalicza się: bicie, kopanie, plucie, wymuszanie pieniędzy, niszczenie własności, natomiast do pośredniej włączanie innych osób z otoczenia do atakowania ofiar w różny sposób. Przemoc słowna bezpośrednia może występować poprzez wyzywanie, przezywanie, wyśmiewanie, ośmieszanie, obrażanie i grożenie innej osobie, natomiast pośrednia poprzez namawianie innych do tego typu zachowań, rozpowszechnianie plotek. Niewerbalna forma przemocy bezpośredniej w środowisku szkolnym objawia się poprzez np.grożenie i pokazywanie nieprzyzwoitych gestów, natomiast pośrednia poprzez rozmyślne wykluczanie z grupy czy działań poprzez izolowanie osoby poszkodowanej [2].

Bardziej pobłażliwie jest traktowana przemoc ze strony rówieśników niż przemoc ze strony osób dorosłych. Doświadczanie przemocy ze strony rówieśników wywiera znaczący wpływ na rozwój psychospołeczny dziecka oraz jego zachowanie w dorosłym życiu. 
Doświadczenie w życiu przemocy rówieśniczej może powodować problemy takie jak: depresja, samotność, wycofanie, niepokój, a także dolegliwości somatyczne i niedostosowanie społeczne [3].

Przemoc domowa, inaczej zwana jest przemocą rodzinną może mieć charakter fizyczny, psychiczny, seksualny i ekonomiczny. Wbrew powszechnie występującym stereotypom dotyczy nie tylko rodzin z tzw. marginesu społecznego, ale także rodzin dobrze usytuowanych. Przemoc pojawiająca się $\mathrm{w}$ rodzinie nie należy do zdarzeń incydentalnych, ma powtarzalny charakter, obserwuje się następujące po sobie fazy: fazę narastania napięcia, ostrej przemocy oraz fazę miodowego miesiąca.

Uwzględniając stan emocjonalny sprawcy przemoc domową dzieli się na: przemoc chłodną (instrumentalną) oraz przemoc gorącą (spontaniczną). Realizowanie specyficznego scenariusza przez sprawcę przemocy jest określane jako przemoc chłodna z premedytacją i zemstą. Sprawcy towarzyszy chłód emocjonalny oraz spokój, emocje są kontrolowane i stłumione. Chłodna przemoc prowadzona przez dorosłych opiekunów wobec dzieci przybiera często formę surowych kar, konsekwentnych metod wychowawczych, sprawiedliwego karania. W przeciwieństwie do przemocy chłodnej, przemocy gorącej towarzyszą gwałtowne, intensywne, negatywne uczucia agresji, złości, gniewu, frustracji, niekiedy rękoczyny, wyzwiska słowne, zadawanie bólu. Przemoc pojawia się nagle i szybko zanika. Konsekwencją występowania przemocy w środowisku rodzinnym jest niska samoocena, niepewność, chwiejność emocjonalna, nieuzasadnione reakcje lękowe, zaburzenia uwagi i koncentracji, poczucie ciągłego zagrożenia. Ofiary przemocy bardzo często popadają $\mathrm{w}$ depresję, stosunkowo łatwo uzależniają się od alkoholu, innych substancji psychoaktywnych, odczuwają psychosomatyczne dolegliwości [4].

Głównym celem przeprowadzonego badania była ocena powszechności zjawiska przemocy wśród uczniów włocławskich szkół, form przemocy występującej w środowisku szkolnym, 
identyfikacja problemu przemocy $\mathrm{w}$ środowisku rodzinnym oraz określenie odsetka uczniów, które poinformowały osoby dorosłe o stosowanej wobec nich przemocy.

\section{Materiał i metody}

Badanie zjawiska przemocy rówieśniczej i domowej zostało przeprowadzone wśród dzieci i młodzieży ze szkół zlokalizowanych na terenie miasta Włocławek w 2017 r. Zastosowano metodę sondażu diagnostycznego, przy użyciu kwestionariusza ankiety własnego autorstwa. W badaniu uczestniczyło 369 uczniów szkoły podstawowej, klas gimnazjalnych szkoły podstawowej oraz szkoły średniej. Badanie stanowiło część większych badań dotyczących zachowań dzieci i młodzieży. Na wykonanie badań uzyskano zgodę Komisji Bioetycznej przy Kujawsko-Pomorskiej Okręgowej Izbie Lekarskiej w Toruniu.

Najliczniejszą grupę stanowili uczniowie Szkoły Podstawowej 147 osób (39,8\%). Do szkoły średniej uczęszczało 117 osób $(31,7 \%)$. Najmniej liczną grupą byli uczniowie klas gimnazjalnych w szkole podstawowej - 105 osób (28,5\%). Wśród uczestników badania przeważały dziewczęta (213 osób -57,7\%), w porównaniu do chłopców (156 osób - 42,3\%). Rodziny dzieci ankietowanych najczęściej określano mianem rodzin pełnych (81,6\% badanych). Jedynie 3\% spośród badanych wskazało, że jedno z rodziców pracuje za granicą. Śmierć obojga rodziców podała 1 osoba $(0,3 \%)$. Ponad $73 \%$ badanych posiadało rodzeństwo. Rodzice zdecydowanej większości uczniów (68,6\% osób) są czynni zawodowo; tylko 3,0\% badanych wskazało, że oboje rodziców nie pracuje.

\section{Wyniki}

Z przeprowadzonych badań wynika, że zdecydowana większość uczniów - $(67,2 \%)$ zadeklarowała brak doświadczania 
przemocy w szkole. Jednak problem ten dotyczy 32,8\% uczniów. Najczęściej przemocy doświadczali uczniowie szkół podstawowych (40,1\%), następnie uczniowie klasy gimnazjalnej w szkole podstawowej. Najrzadziej doświadczali przemocy uczniowie szkół średnich $(23,9 \%)$. Wykazano istotną statystycznie różnicę pomiędzy rodzajem szkoły, a zjawiskiem doświadczania przemocy $\mathrm{w}$ szkole $(\mathrm{p}=0,021)$ (Tabela 1$)$.

Tabela 1. Doświadczanie przemocy w szkole w opinii uczniów.

\begin{tabular}{|c|c|c|c|c|c|c|c|c|}
\hline \multicolumn{2}{|l|}{ Rodzaj szkoły } & \multicolumn{2}{|c|}{$\begin{array}{l}\text { Szkoła } \\
\text { podstawowa }\end{array}$} & \multicolumn{2}{|c|}{$\begin{array}{l}\text { Klasa } \\
\text { gimnazjalna } \\
\text { w szkole } \\
\text { podstawowej }\end{array}$} & \multicolumn{2}{|c|}{$\begin{array}{l}\text { Szkoła } \\
\text { średnia }\end{array}$} & \multirow[t]{2}{*}{$\mathbf{P}$} \\
\hline Zagadnienie & Odpowiedź & $\mathbf{N}$ & $\%$ & $\mathbf{N}$ & $\%$ & $\mathbf{N}$ & $\%$ & \\
\hline \multirow{2}{*}{$\begin{array}{l}\text { Czy } \\
\text { doświadczyłeś } \\
\text { /aś } \\
\text { kiedykolwiek } \\
\text { przemocy } \\
\text { w szkole? }\end{array}$} & Tak & 59 & $\begin{array}{l}40, \\
1\end{array}$ & 34 & $\begin{array}{l}32, \\
4\end{array}$ & $\begin{array}{l}2 \\
8\end{array}$ & $\begin{array}{l}23, \\
9\end{array}$ & \multirow[t]{2}{*}{$\begin{array}{l}0,02 \\
1\end{array}$} \\
\hline & Nie & 88 & $\begin{array}{l}59, \\
9\end{array}$ & 71 & $\begin{array}{l}67 \\
6\end{array}$ & $\begin{array}{l}8 \\
9\end{array}$ & $\begin{array}{l}76, \\
1\end{array}$ & \\
\hline
\end{tabular}

Źródło: wynik badań własnych

$\mathrm{Na}$ pytanie „Czy byłeś kiedykolwiek świadkiem przemocy w szkole?" odpowiedź potwierdzającą udzieliło (69,9\%) badanych dzieci, natomiast przeczącej (30,1\%). Najczęściej świadkami przemocy są dzieci w szkole podstawowej (81\%), natomiast najrzadziej w szkole średniej $(52,1 \%)$ badanych. Wykazano istotną statystycznie różnicę pomiędzy rodzajem szkoły, a uczestnictwem jako świadek przemocy przez dzieci $(\mathrm{p}=0,000)$ (Tabela 2$)$.

Tabela 2. Doświadczanie przemocy jako świadek $w$ opinii uczniów. 


\begin{tabular}{|c|c|c|c|c|c|c|c|c|}
\hline \multicolumn{2}{|l|}{ Rodzaj szkoły } & \multicolumn{2}{|c|}{$\begin{array}{l}\text { Szkoła } \\
\text { podstawowa }\end{array}$} & \multicolumn{2}{|c|}{$\begin{array}{l}\text { klasa } \\
\text { gimnazjalna w } \\
\text { szkole } \\
\text { podstawowej }\end{array}$} & \multicolumn{2}{|c|}{$\begin{array}{l}\text { Szkoła } \\
\text { średnia }\end{array}$} & \multirow[t]{2}{*}{$\mathbf{p}$} \\
\hline Zagadnienie & Odpowiedź & $\mathbf{N}$ & $\%$ & $\mathbf{N}$ & $\%$ & $\mathbf{N}$ & $\%$ & \\
\hline \multirow{2}{*}{$\begin{array}{l}\text { Czy byłeś/aś } \\
\text { kiedykolwiek } \\
\text { świadkiem } \\
\text { przemocy } \\
\text { w szkole? }\end{array}$} & Tak & 119 & 81,0 & 78 & 74,3 & $\begin{array}{l}6 \\
1\end{array}$ & $\begin{array}{l}52, \\
1\end{array}$ & \multirow[t]{2}{*}{$\begin{array}{l}0,00 \\
0\end{array}$} \\
\hline & Nie & 28 & 19,0 & 27 & 25,7 & $\begin{array}{l}5 \\
6\end{array}$ & $\begin{array}{l}47 \\
9\end{array}$ & \\
\hline
\end{tabular}

Źródło: wynik badań własnych.

Najczęściej występującym źródłem przemocy na terenie szkoły okazał się inny uczeń w każdym z badanych typów szkół. W szkole podstawowej $96,7 \%$ badanych wskazało jako sprawcę przemocy innego ucznia, w klasie gimnazjalnej szkoły podstawowej 91,4\% badanych, natomiast w szkole średniej 84,7\%. Najrzadziej badani wskazali jako źródło przemocy na terenie szkoły nieznaną osobę dorosłą: w szkole podstawowej $0,8 \%$, w klasie gimnazjalnej szkoły podstawowej 2,5\% i szkole średniej 4,2\% (Tabela 3).

Tabela 3. Źródła przemocy na terenie szkoły w opinii uczniów.

\begin{tabular}{|c|c|c|c|c|c|c|c|c|}
\hline \multicolumn{2}{|l|}{ Rodzaj szkoły } & \multicolumn{2}{|c|}{$\begin{array}{l}\text { Szkoła } \\
\text { podstawowa }\end{array}$} & \multicolumn{2}{|c|}{$\begin{array}{l}\text { Klasa } \\
\text { gimnazjalna w } \\
\text { szkole } \\
\text { podstawowej }\end{array}$} & \multicolumn{2}{|c|}{$\begin{array}{l}\text { Szkoła } \\
\text { średnia }\end{array}$} & \multirow[t]{2}{*}{$\mathbf{P}$} \\
\hline Zagadnienie & Odpowiedź & $\mathbf{N}$ & $\%$ & $\mathbf{N}$ & $\%$ & $\mathbf{N}$ & $\%$ & \\
\hline \multirow{4}{*}{$\begin{array}{l}\text { Kto był } \\
\text { źródłem } \\
\text { przemocy } \\
\text { na terenie } \\
\text { szkoły? }\end{array}$} & inny uczeń & 119 & 96,7 & 74 & 91,4 & 61 & 84,7 & \multirow[t]{4}{*}{0,011} \\
\hline & $\begin{array}{l}\text { znana } \\
\text { Tobie } \\
\text { osoba } \\
\text { dorosła }\end{array}$ & 3 & 2,4 & 3 & 3,7 & 7 & 9,7 & \\
\hline & $\begin{array}{l}\text { nieznana } \\
\text { Tobie } \\
\text { osoba } \\
\text { dorosła }\end{array}$ & 1 & 0,8 & 2 & 2,5 & 3 & 4,2 & \\
\hline & inny uczeń & 0 & 0,0 & 2 & 2,5 & 1 & 1,4 & \\
\hline
\end{tabular}




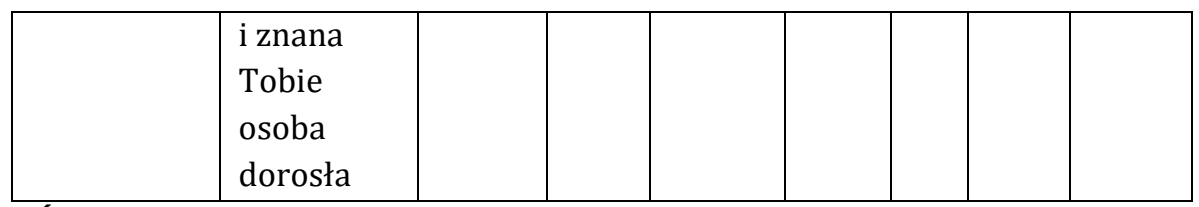

Źródło: wynik badań własnych.

Najczęstszą formą przemocy wśród uczniów były przekleństwa, doświadczane przez 24,5\% uczniów. Kłótni (19,9\%) i wyśmiewania się $(21,4 \%)$ doznało $w$ podobnym stopniu procentowym, a gróźb pobicia 9,4\% uczniów. Nie wykazano istotnej pod względem statystycznym różnicy $(\mathrm{p}=0,535)$ (Tabela 4$)$.

Tabela 4. Formy przemocy wśród opinii uczniów.

\begin{tabular}{|c|c|c|c|}
\hline Formy przemocy & Liczba & $\%$ & $\mathbf{P}$ \\
\hline Przekleństwa & 253 & 24,5 & \multirow{9}{*}{0,535} \\
\hline Kłótnie & 206 & 19,9 & \\
\hline Wyśmiewanie się & 221 & 21,4 & \\
\hline Groźby pobicia & 97 & 9,4 & \\
\hline Pobicie & 111 & 10,7 & \\
\hline Niszczenie rzeczy & 86 & 8,3 & \\
\hline Wymuszenia & 49 & 4,7 & \\
\hline Inne & 11 & 1,1 & \\
\hline Razem & 1034 & 100,0 & \\
\hline
\end{tabular}

Źródło: wynik badań własnych.

Wyniki przeprowadzonych badań wskazują, że zdecydowana większość uczniów - $(63,7 \%)$ nie doświadczyło kiedykolwiek żadnej formy przemocy $\mathrm{w}$ swojej rodzinie. Natomiast 36,3\% uczniów doświadczyło przemocy $\mathrm{w}$ rodzinie. Najwięcej dzieci, które odpowiedziały twierdząco na to zagadnienie było uczniami szkoły podstawowej19,2\% i szkoły średniej 18,2\% (Tabela 5).

Tabela 5. Przemoc w rodzinie w opinii uczniów. 


\begin{tabular}{|l|l|l|l|l|l|l|l|l|}
\hline \multicolumn{2}{|l|}{ Rodzaj szkoły } & \multicolumn{2}{|l|}{$\begin{array}{l}\text { Szkoła } \\
\text { podstawowa }\end{array}$} & \multicolumn{2}{|l|}{$\begin{array}{l}\text { Klasa } \\
\text { gimnazjalna w } \\
\text { szkole } \\
\text { podstawowej }\end{array}$} & $\begin{array}{l}\text { Szkoła } \\
\text { średnia }\end{array}$ & p \\
\hline Zagadnienie & Odpowiedź & $\mathbf{N}$ & $\%$ & $\mathbf{N}$ & $\%$ & $\mathbf{N}$ & $\%$ & \\
\hline $\begin{array}{l}\text { Czy } \\
\text { doświadczyłeś } \\
\text { /aś } \\
\text { kiedykolwiek } \\
\text { przemocy } \\
\text { w swojej } \\
\text { rodzinie? }\end{array}$ & Nie & 172 & 80,8 & 130 & 83,3 & $\begin{array}{l}30 \\
2\end{array}$ & $\begin{array}{l}81, \\
8\end{array}$ & $\begin{array}{l}0,52 \\
6\end{array}$ \\
\cline { 2 - 7 } & Tak & 41 & 19,2 & 26 & 16,7 & 67 & $\begin{array}{l}18, \\
2\end{array}$ & \\
\hline
\end{tabular}

Źródło: wynik badań własnych.

Odsetek dzieci który mówił o stosowanej w domu wobec niego/niej przemocy, 19,5\% w szkole podstawowej, 7,7\% w klasie gimnazjalnej szkoły podstawowej, $14,9 \%$ w szkole średniej. Natomiast odsetek dzieci który nie mówił o stosowanej w domu przemocy 80,5\% w szkole podstawowej, 92,3\% w klasie gimnazjalnej szkoły podstawowej oraz $85,1 \%$ w szkole średniej (Tabela 6).

Tabela 6. Informowanie dorosłych o stosowanej formie przemocy wśród dzieci w opinii uczniów

\begin{tabular}{|c|c|c|c|c|c|c|c|c|}
\hline \multicolumn{2}{|l|}{ Rodzaj szkoły } & \multicolumn{2}{|c|}{$\begin{array}{l}\text { Szkoła } \\
\text { podstawowo }\end{array}$} & \multicolumn{2}{|c|}{$\begin{array}{l}\text { klasa } \\
\text { gimnazjalna w } \\
\text { szkole } \\
\text { podstawowej }\end{array}$} & \multicolumn{2}{|c|}{$\begin{array}{l}\text { Szkoła } \\
\text { średnia }\end{array}$} & \multirow[t]{2}{*}{$\mathbf{p}$} \\
\hline Zagadnienie & Odpowiedź & $\mathbf{N}$ & $\%$ & $\mathbf{N}$ & $\%$ & $\mathbf{N}$ & $\%$ & \\
\hline \multirow[b]{2}{*}{$\begin{array}{l}\text { Czy } \\
\text { powiedziałeś } \\
\text { /aś } \\
\text { o stosowanej } \\
\text { w domu } \\
\text { wobec Ciebie } \\
\text { przemocy? }\end{array}$} & Nie & 33 & 80,5 & 24 & 92,3 & 57 & 85,1 & \multirow[t]{2}{*}{0,167} \\
\hline & Tak & 8 & 19,5 & 2 & 7,7 & 10 & 14,9 & \\
\hline
\end{tabular}

Źródło: wynik badań własnych. 


\section{Dyskusja}

Zjawisko przemocy jest powszechne i obserwowane w szkołach. Zespoły badawcze Instytutu Socjologii UW przeprowadziły sondaże na reprezentatywnych ogólnopolskich próbach. Ich celem było określenie skali problemu przemocy szkolnej oraz zrozumienie tego zjawiska. Wyniki badań zostały opublikowane w postaci raportów: lipiec 2011 [5]oraz maj 2011 [6].

Dokonano także porównań skali zjawiska i dynamiki zmian w ciągu ostatnich lat 2006 vs 2011, przy zastosowaniu tej samej procedury doboru próby, tych samych pytań kwestionariuszowych. Uzyskane dane wskazują, że nie wystąpiły wyraźne zmiany od 2006 roku, $\mathrm{z}$ niewielkim wzrostem skali agresji werbalnej, relacyjnej i wymuszeń o charakterze niematerialnym. Większość (63\%) uczniów nie uważa, że przemoc jest poważnym problemem w ich szkole, nieco więcej niż jedna czwarta (27\%) stwierdza, że przemoc jest poważnym problemem $\mathrm{z}$ czego tylko $12 \%$ zdecydowanie zgadza się $\mathrm{z}$ tym stwierdzeniem [6].

Wyniki przeprowadzonych badań wykazały, że większość uczniów - $(69,1 \%)$ przyznaje, że była świadkiem przemocy w szkole częściej takie deklaracje składali uczniowie szkół podstawowych $(81,0 \%)$ i klasy gimnazjalnej szkoły podstawowej (74,3\%). Brak przemocy w szkole deklaruje 67,2\% uczniów, z kolei występowanie tego zjawiska potwierdza 32,8\% uczniów. Porównując uzyskane wyniki z badaniami młodzieży włocławskiej w 2012 roku wynika, że zdecydowana większość uczniów - $(78,10 \%)$ zadeklarowała brak doświadczania przemocy $\mathrm{w}$ szkole. Jednak problem ten dotyczy co piątego ucznia w szkole - $(21,90 \%)$ [7].

Według przeprowadzonych badań problem przemocy w szkole dotyczy 40,1\% uczniów szkoły podstawowej, 32,4\% uczniów klasy gimnazjalnej szkoły podstawowej i 23,9\% uczniów szkoły średniej. Według badań Przewłocka J. 2015 r. odsetek uczniów deklarujących, że byli dręczeni w ciągu czterech tygodni poprzedzających badanie 
wynosi 15\% dla uczniów szkoły podstawowej, 10\% uczniów gimnazjum i około 6\% uczniów szkół średnich [8].

W większości przypadków agresja rówieśnicza jest najbardziej nasilona $\mathrm{w}$ gimnazjach, najmniej $\mathrm{w}$ szkołach ponadgimnazjalnych. Aktualnie przeprowadzone badania potwierdzają najmniejszą częstotliwość przemocy $\mathrm{w}$ szkołach średnich, natomiast największe nasilenie występuje w szkole podstawowej.

Przeprowadzone badania własne (2017) wykazały, że większość uczniów najczęściej doświadcza przemocy ze strony swoich koleżanek i kolegów (92\%). Niewielki procent wskazuje na znaną - $(4,7 \%)$ lub nieznaną - $(2,2 \%)$ osobę dorosłą.

Dla porównania przeprowadzone w 2012 roku badania wykazały, że większość uczniów najczęściej doświadcza przemocy ze strony swoich koleżanek i kolegów $(94,17 \%)$. Niewielki procent wskazuje na znaną - $(3,27 \%)$ lub nieznaną - $(2,59 \%)$ osobę dorosłą [7].

Według raportu z badania Przewłocka J. 2015 r. najwyższe natężenie zachowań agresywnych notuje się wśród uczniów klas IV-VI szkół podstawowych, niższe dla gimnazjów i znacznie niższe dla szkół ponadpodstawowych, w szczególności liceum. Częściej występuje agresja w sferze słownej i relacyjnej niż agresja fizyczna [8].

Według przeprowadzonych badań najczęstszą formą przemocy wśród uczniów były: przekleństwa, kłótnie i wyśmiewanie. Podobne wyniki uzyskano w badaniu Komendant-Brodowska A. i wsp. najczęstszą formą agresji była agresja werbalna, którą zadeklarowało $66 \%$ chłopców i 60\% dziewcząt [9].

Z kolei według badania Przewłocka J. 2015 r około połowy uczniów szkół podstawowych (klasy IV-VI) i gimnazjów oraz co trzeci uczeń szkoły ponadgimnazjalnej doświadczył różnych form agresji relacyjnej, takich jak obgadywanie, izolowanie, nastawianie klasy przeciwko konkretnemu uczniowi. Mniej przebadanych uczniów było wyzywanych, obrażanych. Na trzecim miejscu pod względem częstotliwości są zachowania związane $\mathrm{z}$ ośmieszaniem czy poniżaniem [8]. 
Na trzecim miejscu według przeprowadzonych badań również znajduje się wyśmiewanie jako forma agresji.

Badania przeprowadzone w 2007 roku przez CBOS w ramach kampanii społecznej Szkoła bez przemocy wskazują, że najczęstszymi formami agresji wśród uczniów jest obrażanie (wymyślanie) (41,5\%). Najrzadsze są formy przemocy fizycznej.

Wyniki badań z 2006 r. i 2011 r. w ramach programu Szkoła bez przemocy potwierdzają nasilenie problemu agresji i przemocy w szkole, przybierając coraz to nowsze formy. Według raportu problem przemocy występuje częściej w szkołach gimnazjalnych (ponad 75\% gimnazjalistów) doświadczyło różnych form przemocy i agresji, z których dominującą formą była agresja werbalna [10].

Wyniki przeprowadzonych badań wskazują, że zdecydowana większość uczniów - $(81,8 \%)$ nie doświadcza żadnej formy przemocy w swojej rodzinie. Jednak co dziesiąty uczeń - $(14,9 \%)$ przyznał, że doznał przemocy w środowisku rodzinnym.

Dla porównania wyniki badań z 2012 roku wskazują, że zdecydowana większość uczniów - (88,99\%) nie doświadcza żadnej formy przemocy w swojej rodzinie. Jednak co dziesiąty uczeń (11,01\%) przyznał, że doznał przemocy w środowisku rodzinnym [7].

W aktualnych badaniach (2017) uczniowie w zdecydowanej większości - $(85,1 \%)$ nie poinformowali nikogo o stosowanej w domu wobec nich przemocy a tylko nieznaczny odsetek to uczynił $(14,9 \%)$.

Z innych badań wynika, że przemocy werbalnej - nie doświadczyło jedynie 37\% uczniów. Oznacza to, że niemal dwie trzecie uczniów przynajmniej raz było obrażanych, przezywanych czy też wyśmiewanych. Natomiast zdecydowana większość uczniów była świadkiem tej formy przemocy wobec koleżanek i kolegów [6].

Badania przeprowadzone w 2007 roku przez CBOS w ramach kampanii społecznej Szkoła bez przemocy wskazują, że najczęstszymi formami agresji wśród uczniów jest obrażanie (wymyślanie) (41,5\%). Najrzadsze są formy przemocy fizycznej [11]. 
W badaniach CBOS 2016 Przemoc psychiczna jest najczęściej osobiście spotykaną formą przemocy -w ciągu ostatniego roku szkolnego doznało jej $21 \%$ uczniów, w tym $11 \%$ wielokrotnie. Kradzieży pieniędzy lub jakiegoś przedmiotu doświadczyło osobiście 11\% uczniów, w tym $2 \%$ niejeden raz. Natomiast rozboje (zabranie pieniędzy lub przedmiotu przy użyciu siły lub zagrożeniu jej użyciem) zdarzały się incydentalnie - ich ofiarą padło 2\% uczniów. Rzadziej występującymi formami przemocy są: przemoc fizyczna, czyli uderzenie lub pobicie - doznało jej 6\% uczniów, oraz przemoc seksualna, której osobiście doświadczyło 2\% uczniów. Kolejną częściej spotykaną formą jest cyberprzemoc/ nie badana w tym raporcie/. Obraźliwego SMS-a lub maila od koleżanki/kolegi ze szkoły dostało 8\% uczniów i także $8 \%$ badanych znalazło się $\mathrm{w}$ sytuacji, że opublikowano w internecie informacje/zdjęcia, których nie chcieli ujawnić (w obu przypadkach połowa $\mathrm{z}$ nich zetknęła się $\mathrm{z}$ cyberprzemocą niejeden raz). W sumie cyberprzemoc dotknęła 13\% uczniów: przy czym 3\% zetknęło się $\mathrm{z}$ obiema formami tej przemocy, a po $5 \%$ badanych - tylko z jedną $\mathrm{z}$ nich [12].

Dla porównania wyniki badań z 2012 roku wskazują, że zdecydowana większość uczniów - (88,99\%) nie doświadcza żadnej formy przemocy $\mathrm{w}$ swojej rodzinie. Jednak co dziesiąty uczeń (11,01\%) przyznał, że doznał przemocy w środowisku rodzinnym [7].

Natomiast z Raportu z badań prowadzonych na obszarze miasta Włocławka w roku 2009 wynika, że wg deklaracji badanych uczniów z nich 27 było świadkiem lub ofiarą agresji w swoim domu; 13 uczniów było świadkami przemocy, 10- ofiarami, a 4 świadkami i ofiarami. Akty agresji, których świadkami byli badani, zwykle miały miejsce sporadycznie, ale występowały częściej niż jeden raz. Źródłem przemocy był jeden z rodziców (lub oboje), brat lub siostra lub inna osoba dorosła [13].

\section{Wnioski}


1. Zdecydowana większość uczniów $67,2 \%$ zadeklarowała brak doświadczania przemocy w szkole. Problem przemocy dotyczy $32,8 \%$ badanych uczniów.

2. Najczęściej przemocy doświadczają uczniowie szkół podstawowych 40,1\%, najrzadziej uczniowie szkół średnich $23,9 \%$.

3. Większość uczniów $69,9 \%$ przyznaje, że była świadkiem przemocy w szkole - częściej deklaracje składają uczniowie szkół podstawowych 81,0\%.

4. Najczęstszą formą przemocy $\mathrm{w}$ środowisku szkolnym są: przekleństwa, wyśmiewanie, kłótnie.

5. Zdecydowana większość uczniów $63,7 \%$ nie doświadcza żadnej formy przemocy w swojej rodzinie. Odsetek uczniów, którzy zadeklarowali, że doznali przemocy $\mathrm{w}$ środowisku rodzinnym wynosi $36,3 \%$.

6. Uczniowie $\mathrm{w}$ zdecydowanej większości nie poinformowali nikogo o stosowanej w domu wobec nich przemocy.

\section{Zalecenia da praktyki pielęgniarskiej}

Istotny problem $\mathrm{w}$ diagnozowaniu przemocy stanowi niechęć niektórych dzieci (uczniów) do przyznania się do bycia ofiarą przemocy/dręczenia. Ofiary przemocy obawiają się jeszcze większej izolacji, nasilenia stopnia przemocy i zemsty. Bardzo ważne jest wstępne identyfikowanie przez personel medyczny i wychowawców uczniów doświadczających przemocy. Jedną z pierwszych osób, która ma możliwość rozpoznania symptomów przemocy jest pielęgniarka szkolna, która uczestniczy w interdyscyplinarnej opiece nad dzieckiem. Pomoc potrzebna jest także uczniom doświadczającym przemocy nie tylko w środowisku szkolnym, ale również w środowisku domowym.

\section{Bibliografia/Bibliography:}


1. Poraj G. Doświadczanie agresji i przemocy w szkole. Acta Universitatis Lodziensis Folia Psychologic. 2004; 8: 19-31.

2. Kołodziejczyk J. Agresja i przemoc w szkole. Konstruowanie programu przeciwdziałania agresji i przemocy w szkole. NODN „SOPHIA”, Kraków 2004.

3. Włodarczyk J. Przemoc rówieśnicza. Wyniki Ogólnopolskiej diagnozy problemu przemocy wobec dzieci. Dziecko krzywdzone. Teoria, badania, praktyka. 2013; 12 (3):63-81.

4. Łepecka-Klusek C., Pawłowska-Muc A.K., Pilewska-Kozak A.B. Stadnicka G., Pałucka K. Przemoc domowa. Journal of Education, Health and Sport. 2015;5(6):169-182.

5. Komendant-Brodowska A., Giza-Poleszczuk A., Baczko-Dombi A. Przemoc w szkole. Raport z badań, lipiec 2011. Instytut Socjologii UW. Retrieved March 24, 2018 from https://panoptykon.org/sites/default/files/sbp2_szkoly_ost_wersjapdf.pdf

6. Giza-Poleszczuk A., Komendant-Brodowska A., Baczko-Dombi A. Przemoc w szkole. Raport z badań, maj 2011. Instytut Socjologii UW. Retrieved March 24, 2018 from file:///C:/Users/Paulina/Downloads/318-sbp2011-raport-glownycalosc.pdf

7. Diagnoza lokalnych problemów uzależnień i innych zagrożeń społecznych dla miasta Włocławek, Raport przygotowany na zlecenie Urzędu Miasta Włocławek NrPZPS.8141.1.21.2012-1. Włocławek 2012.

8. Przewłocka Jadwiga. Bezpieczeństwo uczniów i klimat społeczny w polskich szkołach. Raport z badania. Retrieved March 24, 2018 from file:///C:/Users/Paulina/Downloads/IBE-raport-PrzemocKlimat-w-szkole.pdf 
9. Komendant-Brodowska A., Baczko-Dombi A., Giza-Poleszczuk A. Przemoc w szkole. Raport z badań. Retrieved March 24, 2018 from http://www.szkolabezprzemocy.pl/1391,przemoc-w-szkolemaj-2011.

10. Przybysz -Zaremba M., Katkoniene A. Profilaktyka agresji i przemocy w szkole w optyce edukacyjnej. Społeczeństwo i Rodzina 2014, 38 (1): 48-62.

11. Raport CBOS w ramach kampanii społecznej Szkoła bez przemocy 2007.

12. Kalka J. Raport z badania sfinansowanego przez Krajowe Biuro ds. Przeciwdziałania Narkomani i Warszawa, 2016 - Badanie „Konsumpcja substancji psychoaktywnych przez młodzież Młodzież 2016. Retrieved March 24, 2018 from file:///C:/Users/Paulina/Downloads/Mlodzież\%202016_raport\%2 0z\%20badania.pdf

13. Diagnoza lokalnych problemów uzależnień i innych zagrożeń społecznych dla miasta Włocławek, Raport przygotowany przez Inqesta, 2009. 